\title{
The Economic Growth Effect of Logistics Industry FDI Analysis
}

\author{
Yang Wang ${ }^{1}$, Luqian Wang ${ }^{2}$
}

${ }^{1}$ School of Management Dalian Jiaotong University, Dalian, China; ${ }^{2}$ Sun Wah International Business School of Liaoning University,
Liaoning, China.
E-mail: wangyang@djtu.edu.cn, wangluqian@dl.cn

Received June 12 $2^{\text {th }}, 2010$; revised August $28^{\text {th }}, 2010$; accepted October $7^{\text {th }}, 2010$.

\begin{abstract}
Based on the direction of the international FDI changed, from manufacturing to service industries, we should concern about the influence of the introduction of China's logistics industry FDI to the national economy. The paper sets up regression model to examine logistics FDI and GDP in two aspects of time series and growth rate, we find that the logistics FDI reaches a high correlation with GDP, and logistics FDI is one of the major driving forces of economic development. Therefore, China should expand the introduction of logistics FDI, improve the quality of foreign investment, develop the positive economic growth effect of logistics FDI and promote the change of China's economic growth pattern to ensure the development of China's economy.
\end{abstract}

Keywords: Logistics, FDI, GDP, Effect

\section{Introduction}

\subsection{International Research}

Jordan Shan [1] used vector autoregressive method to research the relationship between China's FDI and economic growth, and used the variance and impulse respond function to analyze the interaction between FDI and economic growth. Concluded that: economic growth and FDI exist the relationship of two-way causality and the impact of the economic growth on FDI is greater than the impact of FDI on economic growth; the inflow of FDI accelerates the difference between eastern and western areas; the exchange rate doesn't affect FDI in China. Cheng Lsiao used VAR method to analyze the total time series of China and other 23 developing countries, and concluded that: the relationship between GDP and FDI is promoting interaction; except for economic factors, stable and reliable organization and the development of urbanization have a great influence on the introduction of FDI, which are an important factor in promoting economic growth. Sinica Kusic emphasized the importance of FDI to Croatian economy. Author analyzed the influence of FDI to economic growth in the period of transition by the regression and the experience of the similar

Note: This paper is the part of the results of science and technology projects in Liaoning Province, Number [2009401011], contract number [2009040148-304]. countries (e.g. Hungary), providing that the influence of FDI to the economic growth of Croatia, especially in transition period.

Chandana Chakraborty and Parantap Basu [2] used cointegration and error correction model to research on the relationship between India's FDI inflow and economic growth. They thought: FDI and GDP exist longrun equilibrium; the share of unit labor cost and import tax in revenue influences the long-term relationship between FDI and GDP.

\subsection{Demastic Research}

1) The research on FDI and economic growth effect. Li Yining put forward the influence of FDI to China's economic growth in "China's economic growth and fluctuations", which can be divided into direct and indirect effects. Direct effect is the impact of FDI on China's capital formation, and the impact of the productive capacity of FDI on national income. Indirect effect is the impact on exports, technological progress and the demonstration effect, but the theory and data are inadequate. Xia Jingwen proposed that FDI promotes economic growth in five aspects. First, FDI compensates China's funding gap. Second, FDI promotes the technological progress. Third, FDI improves and enhances the trade structure. Fourth, FDI produces the employment effect. Fifth, FDI contributes to China's institutional change. Meawhile Xia Jing- 
wen also proposed that FDI has a negative effect on China's economic growth. Restrict the improvement of international competitiveness of Chinese industries by equity, brand, technology and market control; reduce the external solvency of China's current by physical and technological investment; increase the money supply and inflationary pressure. He analyzed more thoroughly on the influence of FDI to economic growth, but remained in the qualitative analysis. Chen Jiyong, Xiao Weiguo and Wang Qingping discussed the influence of national direct investment to investor, the host country and the world economy from theoretical and empirical aspects, analyzed since 1980s the development of FDI and the impact on China's economic development, and concluded since reform and opening up the basic experience and the main problems of using FDI.

In above studies, some analyze from the point of the investor (TNC), some from the evaluation of the host country, and these analysis and evaluation are discussed since 1980s in the large environment of the overall development of international direct investment and economic development, so it has a strong generality and sense of the times. The choice of FDI industry in developed counties depends on the technical capabilities and competitiveness of developing countries, if the technical capabilities and competitiveness of developing countries are stronger, developed countries tend to transfer more advanced technology to developing countries. Whether FDI can bring technological progress and economic growth to developing countries, it relies on human capital accumulation. Only accompanied by a faster accumulation of human capital, FDI can bring technological progress and economic growth to developing countries.

2) Services FDI and economic growth effect. The literature of services FDI of economic growth effect is limited [3]. Chinese scholars use different methods to get some useful conclusions. The unit root test, cointegration test and Granger causality test are used most. He Meiying, Dau Feng and Hu Yun all used these methods and related data to examine the relationship between China service industry and services growth of FDI, and achieved the similar conclusions, which are that services FDI is the reason of the growth of China services, but reverse is not that. Zha Donglan, Wu Xiaolan used 1998- 2003 data from the various service industries in Jiangsu province, and got the conclusion that FDI in the major industry of services has different effects on industry economic growth, in which introducing foreign investment to real estate makes great contribution to regional GDP, followed by logistics industry (transport, storage, communications), scientific research and integrated technical services, and social services isn't significant impact on regional GDP. Wang Xinhua used the fixed effects model and 1997-2005 data from the various industries of services to do long-term and short-term effects analysis, and the result showed that services FDI has a certain economic growth effect, but quite different in different periods of time. Wei Zuolei used an extended C-D production function to estimate the average contribution rate of FDI to the growth of China's agriculture, industry and services, and the result showed that the average contribution rate of FDI to China's industry is far more than agriculture and services, and the average contribution rates of industry, services and agriculture are respectively $3.69 \%, 0.37 \%$ and $1.48 \%$. According to available data, Jiang Xiaojuan [4] estimated that 2001 and 2002 contribution rate of FDI enterprises to services growth are $17.6 \%, 17.3 \%$, much lower than the industry. (2001 and 2002 , in the total growth of national industrial added value, the contribution rate of FDI enterprises are respectively $39.1 \%, 39.8 \%$ ).

\section{Logistics Industry FDI and China's Economic Growth}

\subsection{The Correlation Analysis of Logistics Industry FDI and GDP}

Based on 1998-2008 statistical data from "China statistical yearbook" [5], we do the correlation analysis and time series analysis for the relationship between logistics FDI and China's economic growth, analyze the internal relationship between the growth of logistics FDI and China's economic growth, and argue the effect of logistics FDI to China's economic growth. According to the availability of China's public data, this part chooses the most representative data of Chinese third-party logistics to analyze (see Table 1).

Investigate the influence of logistics FDI (TFDI for short) to GDP, TFDI as explanatory variable, GDP as dependent variable, and use the regression equation for quantitative analysis to research the relationship of both. First, according to 1997-2007 data, calculate the correlation coefficient between two variables, that is $r=0.52$, and two variables exist certain correlation, but not significant. This is mainly because before 2005 logistics FDI in China also has policy restrictions, not open the whole industry, and policy barriers lead to low foreign investment. The input of manufacturing industry to logistics is calculated to the manufacturing industry, and the data before 2005 can't fully reflect the fact of logistics FDI. Therefore, consider the effectiveness and comprehensiveness of data, select 2007 data of "China statistically ear book" to establish the empirical formula between the two, set $\mathrm{X}$ as the stock of FDI, Y as GDP, and the regression equation is:

$$
Y=\alpha+\beta X+\mu
$$


Table 1. 1997-2007 China's GDP and transport industry FDI.

\begin{tabular}{ccc}
\hline Year & $\begin{array}{l}\text { The actually used FDI of transport, } \\
\text { storage and communications } \\
\text { (thousand dollars) }\end{array}$ & $\begin{array}{c}\text { GDP } \\
\text { (billion yuan) }\end{array}$ \\
\hline 1997 & 1655130 & 7897.30 \\
1998 & 1645130 & 8440.23 \\
1999 & 1551140 & 8967.71 \\
2000 & 1011880 & 9921.46 \\
2001 & 908900 & 10965.52 \\
2002 & 913460 & 12033.27 \\
2003 & 867370 & 13582.28 \\
2004 & 1272850 & 15987.83 \\
2005 & 1812300 & 18321.74 \\
2006 & 1984850 & 21192.35 \\
2007 & 2006760 & 24952.99 \\
\hline
\end{tabular}

Source: 1998-2008 China statistical yearbook

In the equation, $\alpha, \beta$ as to be estimated coefficients, $\mu$ as random error term, use the above statistics to estimate the equation, and the estimated result is: $Y=$ $39757.38+0.91 X$ (Table 2).

In the regression equation, the degree of freedom is 9 , the critical value $F(1,9)=5.12$, while the test value $F$ is $39.5, \mathrm{~F}>\mathrm{F}(1,9)$, which shows that the general linear equation is significant in the $95 \%$ level; $R^{2}=0.8877$ shows that the goodness of fit between TFDI and GDP is higher. The regression equation illustrates that China's logistics industry increases 10000 dollars in FDI which will increase 91 million yuan in GDP, in another words, the need effect of logistics FDI to the current GDP is obvious (Table 3).

\subsection{The Time Series Analysis of TFDI and GDP}

FDI to economic growth primarily produces two effects, namely short-term demand-pull effect and long-term supply effect. Use GDP over the years as independent variable, the FDI (100 million U.S. dollars) of transportation, storage and telecommunications as explanatory variable, do the econometric tests (samples interval 2001-2007) from the perspective of time series analysis, do the correlation analysis by SPSS, use the multiple lag distribution model to do the econometric tests, so the regression equation is:

Table 2. The parameter estimates and the test values of simple linear regression.

\begin{tabular}{ccccc}
\hline Variable & Coefficient & Std. Error & t-Statistic & Prob. \\
\hline C & 39757.38 & 21472.98 & 1.851507 & 0.1233 \\
TFDI & 0.913387 & 0.145319 & 6.285411 & 0.0015 \\
R-squared & 0.887657 & Mean dependent var & 167194.3 \\
S.E. of regression & 18710.57 & Akaike info criterion & 22.74652 \\
Log likelihood & -77.61282 & F-statistic & 39.50640 \\
\hline
\end{tabular}

Dependent Variable: GDP; Method: Least Squares; Sample: 20012007 ; Included observations: 7 .
Table 3. The parameter estimates and the test values of multiple linear regression.

\begin{tabular}{ccccc}
\hline Variable & Coefficient & Std. Error & t-Statistic & Prob. \\
\hline C & 34933.25 & 2583.991 & 13.51911 & 0.0470 \\
TFDI & 0.589803 & 0.031704 & 18.60327 & 0.0342 \\
TFDI (-1) & -0.161691 & 0.049241 & -3.283680 & 0.1882 \\
TFDI (-2) & 0.706388 & 0.038627 & 18.28736 & 0.0348 \\
R-squared & 0.999804 & Mean dependent var & 188074.4 \\
S.E. of regression & 1244.890 & Akaike info criterion & 17.08204 \\
Log likelihood & -38.70511 & F-statistic & 1697.659 \\
\hline
\end{tabular}

Dependent Variable: GDP; Method: Least Squares; Sample (adjusted): 2001 2005; Included observations: 5 after adjusting endpoints.

$G D P=\beta_{1}+\beta_{2} T F D I+\beta_{3} T F D I_{-1}+\beta_{4} T F D I_{-2}+\delta$

In the regression equation, $\mathrm{Y}(\mathrm{GDP})$ is the increased amount of China's economy, X(TFDI) is the current use of foreign investment in logistics industry, and $\mathrm{X}$ with subscripts $-1,-2$ represent the year before, two years before the foreign investment. Here, the current FDI variable is to explain the short-term demand-pull effect of foreign investment, while the lagged variables are to explain the long-term supply effect of foreign investment.

The result of OLS by statistical analysis shows that $\mathrm{t}$-significance probability of $\mathrm{FDI}^{-1}$ is 0.1882 , higher than 0.05 , which is not significant difference from 0 , indicating that $\mathrm{FDI}^{-1}$ shouldn't appear in the equation. And, tsignificance probability of the constant term, TFDI and $\mathrm{TFDI}^{-2}$ are $0.047,0.0342$ and 0.0348 , all less than 0.05 , indicating that the constant term, TFDI and $\mathrm{TFDI}^{-2}$ are significant difference from 0 , so they should appear in the equation as explanatory variables, the model 1 is:

$G D P=39561.20+0.5 T F D I+0.5979 T F D I_{-2}$

The previous econometric analysis from the perspective of multi-lagged analysis model examines the impact of using foreign investment on the economic growth. The results of OLS from models shows that as R-squared value is high, indicating that the model has better goodness of fit, and $\mathrm{T}$ values and $\mathrm{F}$ values also reach the significant level, so the model is reasonable and effective. The model shows that logistics FDI increases 10000 dollars in the same year which will increase 50 million yuan in GDP (Table 4).

In order to understand well the demand effect and supply effect of logistics FDI, choose FDI and lagged variables as explanatory variables, use the same sample data and the lag distribution model in the form of logarithm to do the econometric test, so the model 2 is:

$L n G D P=2.996797+0.413084 L n F D I+0.361457 L_{n F D I}$ 
Table 4. The parameter estimates and the test values of multiple linear regression model 1.

\begin{tabular}{lcccc}
\hline Variable & Coefficient & Std. Error & t-Statistic & Prob. \\
\hline C & 39561.20 & 5256.804 & 7.525713 & 0.0172 \\
TFDI & 0.500100 & 0.039054 & 12.80523 & 0.0060 \\
TFDI (-2) & 0.597900 & 0.048575 & 12.30880 & 0.0065 \\
R-squared & 0.997687 & Mean dependent var & 188074.4 \\
S.E. of regression & 3021.591 & Akaike info criterion & 19.14866 \\
Log likelihood & -44.87166 & F-statistic & 431.3323 \\
\hline
\end{tabular}

Dependent Variable: GDP; Method: Least Squares; Sample (adjusted): 2001 2005; Included observations: 5 after adjusting endpoints.

Table 5. The parameter estimates and the test values of multiple linear regression model 2.

\begin{tabular}{lclcc}
\hline Variable & Coefficient & Std. Error & t-Statistic & Prob. \\
\hline C & 2.996797 & 0.350559 & 8.548623 & 0.0134 \\
LOG(TFDI) & 0.413084 & 0.030950 & 13.34665 & 0.0056 \\
LOG(TFDI (-2)) & 0.361457 & 0.035572 & 10.16135 & 0.0095 \\
R-squared & 0.997153 & Mean dependent var & 12.12220 \\
S. E. of regression & 0.017886 & \multicolumn{2}{l}{ Akaike info criterion } & -4.925880 \\
Log likelihood & 15.31470 & F-statistic & & 350.1868 \\
\hline
\end{tabular}

Dependent Variable: LOG (GDP); Method: Least Squares; Sample (adjusted): 1997 2004; Included observations: 5 after adjusting endpoints.

In this equation, $\mathrm{F}(350.1868)$ passes the examination, and the regression effect is remarkable, which shows that explanatory variables (the FDI of transport, storage and telecommunications) has a higher interpretation level to the independent variable (GDP), with the overall linear. Meanwhile, in the regression equation, the determination coefficient $R^{\wedge} 2$ and correlation coefficient $R$ are high, indicating that the economic growth extremely depends on logistics FDI (Table 5).

The test of econometric analysis of model 2 meets the requirements, so it's effective. The model means that logistics FDI increases $1 \%$ which promotes economic growth $0.413 \%$. The results of econometric test show that the need effect of FDI to the economic growth is evident. Because logistics FDI generally can't produce supply effect that year, so lagged two years international investment similarly replaces multi-lag distribution model, to analyze the supply effect of logistics FDI. The results of quantitative analysis show that logistics FDI increases $1 \%$ which will bring $0.361 \%$ of the supply effect, so the growth effect of logistics FDI to economic growth is obvious.

The parameters of the above equation pass the significant test, and $R^{2}$ reaches 0.997 , indicating that the explainable function of the equation is strong. From the model of adding lagged variables, we can see that the effect of one-year lag is not clear, and this may be because after logistics FDI enters China, its demand-pull makes contribution on that year, in the period of initial development the supply effect doesn't make much contribution on the following year. During two years development, the supply effect comes into play that makes a large contribution to GDP, so the two-year lag coefficient is quite significant.

\subsection{The Relationship between the Growth Rate of Logistics FDI and China's Economy}

From 1997-2007 the volatility cycle of logistics FDI and GDP, the growth of logistics FDI is identical with the trend of GDP, and the contribution of China's national economy has increased annually. Based on 1997-2007 data of the growth of logistics foreign investment and China's economy, their relationship is done correlation analysis, regression analysis, reflecting the internal relationship between the growth of logistics FDI and economic growth (Table 6).

1) Correlation analysis. Use the growth rate of GDP as economic growth rate, 1997-2007 data as the sample period, research the changing relationship between China's economic growth and FDI growth, and by SPSS we know that the changing relations between the two is $\gamma(G, g)=0.4454$, which shows that the correlation between China's economic growth and logistics FDI is weak. And the promotion of logistics industry FDI to China's economic growth is not significant, which is different from the verification in China's economic development. By analyzing 1997-2007 the economic situation and foreign investment of the major FDI home countries, we find that 2000, in the United States, Britain, Canada, Japan and western Europe the network technology bubble burst, stock prices plummeted and economic was slow-down. The end of 2001, the original world energy giant Enron closed down because of false accounting, more than 20,000 unemployed. Then the United States broke out 9.11, so in 2000-2003, the world FDI severely reduced. But China's economy keeps increasing, the reason is that the expansion of domestic demand and relatively strict capital accounts. In this period, the inflows of FDI become smaller with economic crisis, thus it reduces the correlation between the growth rate of China's economy and FDI growth rate. Therefore, in the following regression analysis, exclude data from 20012003 , in order to more accurately reflect the correlation between variables.

2) Regression analysis. Using the data from the above table to do the multiple regression analysis by SPSS, all the selected variables are forced into the regression, the economic growth rate as independent variable, GDP, total investment in fixed assets, the use of foreign investment, the share of foreign investment, and the growth rate of foreign investment as explanatory variables, sample 
Table 6. 1997-2007 the growth rate of China's economy and the related factors of logistics industry.

\begin{tabular}{|c|c|c|c|c|c|c|}
\hline Year & $\begin{array}{c}\text { Economic } \\
\text { growth rate } \\
(\%)\end{array}$ & $\begin{array}{c}\text { GDP } \\
(10 \text { million } \\
\text { yuan })\end{array}$ & $\begin{array}{l}\text { The scale of fixed assets in- } \\
\text { vestment in logistics industry } \\
\text { (10 million yuan) }\end{array}$ & $\begin{array}{l}\text { The actually used foreign } \\
\text { investment in transport } \\
\text { (10 thousand dollars) }\end{array}$ & $\begin{array}{l}\text { The actually used foreign } \\
\text { investment in transport } \\
\text { (10 thousand dollars) }\end{array}$ & $\begin{array}{l}\text { The } \\
\text { growth } \\
\text { rate }(\%)\end{array}$ \\
\hline 1997 & 9.3 & 78973.0 & 2367.2 & 165513 & 3.66 & - \\
\hline 1998 & 7.8 & 84402.3 & 3401.6 & 164513 & 3.62 & -0.60 \\
\hline 1999 & 7.6 & 89677.1 & 3533.5 & 155114 & 3.85 & -5.71 \\
\hline 2000 & 8.4 & 99214.6 & 3554.7 & 101188 & 2.49 & -34.77 \\
\hline 2001 & 8.3 & 109655.2 & 3956.4 & 90890 & 1.94 & -10.18 \\
\hline 2002 & 9.1 & 120332.7 & 4553.6 & 91346 & 1.73 & 0.50 \\
\hline 2003 & 10.0 & 135822.8 & 5594.4 & 86737 & 1.62 & -5.05 \\
\hline 2004 & 10.1 & 159878.3 & 7570.6 & 127285 & 2.10 & 46.75 \\
\hline 2005 & 10.4 & 183217.4 & 9293.1 & 181230 & 3.00 & 42.38 \\
\hline 2006 & 11.6 & 211923.5 & 1269.4 & 198485 & 3.15 & 9.52 \\
\hline 2007 & 11.9 & 249529.9 & 14281.0 & 200676 & 2.68 & 1.10 \\
\hline
\end{tabular}

Source: (1) Narional data center; other data from 1998-2008 "China statistical yearbook".

Table 7. The parameter estimates and the test values of multiple linear regression model.

\begin{tabular}{|c|c|c|c|c|}
\hline Variable & Coefficient & Std. Error & t-Statistic & Prob. \\
\hline $\mathrm{C}$ & 9.308897 & 0.787260 & 11.82443 & 0.0000 \\
\hline Investment in fixed assets & $-7.15 \mathrm{E}-05$ & $6.83 \mathrm{E}-05$ & -1.047749 & 0.3351 \\
\hline Use of foreign investment & $5.08 \mathrm{E}-05$ & $8.83 \mathrm{E}-06$ & 5.748461 & 0.0012 \\
\hline The growth rate of foreign investment & -0.002186 & 0.009426 & -0.231867 & 0.8243 \\
\hline The proportion of foreign investment & -2.442980 & 0.461542 & -5.293085 & 0.0018 \\
\hline R-squared & 0.903043 & \multicolumn{2}{|c|}{ Mean dependent var } & 9.500000 \\
\hline Log likelihood & -6.314866 & \multicolumn{2}{|c|}{ F-statistic } & 13.97074 \\
\hline Durbin-Watson stat & 2.401482 & \multicolumn{2}{|c|}{ Prob (F-statistic) } & 0.003381 \\
\hline
\end{tabular}

Dependent Variable: GR; Method: Least Squares; Sample: 1997 2007; Included observations: 11.

period of 1997-2007, then the regression equation is:

Economic growth rate $(G)=\beta_{1}+\beta_{2}$ investment in fixed assets $+\beta_{3}$ use of foreign investment $+\beta_{4}$ the proportion of foreign investment $+\beta_{5}$ the growth rate of foreign investment $+\delta$, we can get the estimated results as below (Table 7).

In the regression equation, $F$ (13.97) passes the test and the regression effect is significant, which shows that independent variable (the growth of logistics FDI) has a higher interpretation to explanatory variable (economic growth rate), with general linear. Meanwhile, the determination coefficient $\mathrm{R}^{2}=0.903043$ is quite high in the regression equation, indicating that China's economic growth largely depends on logistics FDI.

\section{Conclusions}

First, from time series and growth rate, logistics FDI is highly relevant to China's economic growth, which is the major factor and driving force of China's economic growth.

Second, China should continue to increase the introduction of foreign investment and logistics supply, to protect national economic development.

Third, China should improve the quality of FDI, promote the optimization and upgrading of logistics structure and economic transition, to promote the economic development.

\section{REFERENCES}

[1] Jordan Shan, "A VAR approach to the economics of FDI in China," Applied Economics, Vol. 34, No. 7, 2002, pp. 885-893.

[2] Parantap Basu, "A New Methodology For Studying The Equity Premium," Royal Economic Society Annual Conference, Royal Economic Society, Vol. 72, 2004.

[3] X. H. Wang, "The Reviews on Economic Effects of Services FDI," The Journal of Shanghai University Business School, June 2009. (In Chinese).

[4] X. J. Jiang, "The Deas, Objectives and Institutional Policies of China's Services Development during 11th FiveYear," Management World, January 2005. (In Chinese).

[5] "National Bureau of Statistics. China Statistical Yearbook," China Statistics Press, 1998-2008. (In Chinese). 